\title{
ПРИМЕНЕНИЕ КОМПЕТНОСТНОГО ПОДХОДА В ОБУЧЕНИИ СТУДЕНТОВ ФАРМАЦЕВТИЧЕСКОГО ФАКУЛЬТЕТА НА КАФЕДРЕ ФАРМАКОЛОГИИ И КЛИНИЧЕСКОЙ ФАРМАКОЛОГИИ
}

Основная цель образования - подготовка квалифицированного специалиста соответствующего уровня и профиля, конкурентоспособного на рынке труда, компетентного, свободно владеющего своей профессией и ориентирующегося в смежных областях деятельности, готового к постоянному профессиональному росту, социальной и профессиональной мобильности. В течение последнего десятилетия основной педагогической стратегией высшего медицинского образования является компетентностный подход в подготовке специалиста. Последовательная реализация компетентностного подхода предполагает системную модернизацию всех составляющих образовательного процесса. В утвержденных в 2019 г. новых компетентностно-ориентированных государственных образовательных стандартах высшего профессионального образования в Российской Федерации по специальностям додипломного медицинского и фармацевтического образования «компетенция» определяется как способность применять знания, умения и личностные качества для успешной деятельности в определенной области [7]. Таким образом, основой компетентностного подхода являются те же элементы, на которых основывалось получение квалификации, но к ним добавляется способность с учетом личностных качеств применять полученные навыки, умения, знания в своей деятельности $[4,6]$. Цель перестройки образования - обеспечить подготовку не ремесленников, способных грамотно выполнять узкий набор операций, а профессионалов, обладающих профессиональным мышлением, готовых всесторонне проявлять свои знания, креативные способности. Современный фармацевтический рынок представляет собой активно развивающийся бизнес, определяющий высокие требования к подготовке конкурентоспособных кадров. Наблюдается повышение зависимости эф- фективности деятельности аптечной организации от её внутреннего потенциала, основу которого составляет фармацевтический персонал [5]. Качество и доступность фармацевтической помощи населению определяется также уровнем сформированности профессионально важных качеств провизора, под которыми понимают профессиональные, личностные, инновационные качества, влияющие на эффективность его труда. Фармацевтическая помощь заключается не только в лекарственном обеспечении населения. Ее главной задачей является содействие безопасному применению лекарственных средств, особенно при реализации безрецептурных лекарственных средств в аспекте «ответственного самолечения». В соответствии с новой парадигмой фармацевтической практики провизоры-рецептары должны обладать знаниями и навыками, необходимыми для рационального консультирования пациентов [1, 9].

В связи с утверждением в конце июля 2017 г. новых компетентностно-ориентированных государственных образовательных стандартов высшего профессионального образования по специальностям додипломного медицинского и фармацевтического образования [2] перед нашей кафедрой возникла необходимость в кратчайшие сроки внести соответствующие изменения в организацию и методическое обеспечение учебного процесса. Были разработаны списки компетенций, которые проверяются на практически-ориентированном экзамене по преподаваемым дисциплинам, внесены изменения в учебные программы и в комплекс учебнометодических материалов (методические указания для студентов, методические рекомендации

(c) С.В. Налётов, Н.В. Конышева, Я.Ю. Галаева,

И.А. Сидоренко, О.С. Налётова, Т.А. Твердохлеб, М.М. Алесинский, Э.Л. Белевцова, 2020

(c) Университетская Клиника, 2020 
для преподавателей, обучающие задания, средства контроля и т.д.); создан банк тестов, ситуационных задач и других средств контроля [8], разработаны наборы материалов для проведения государственного экзамена по клинической фармакологии.

Кафедра фармакологии и клинической фармакологии формирует эти компетенции у студентов-фармацевтов на протяжении 3 курсов. В течение двух семестров изучения фармакологии на 3 курсе (всего 324 ч.) у студентов формируются компетенции, связанные со способностью различать группы и отдельные лекарственные препараты (в том числе генерические), их фармакодинамику. Преподаются основы рецептуры для реализации возможности расчёта и оценки доз лекарственных средств.

В ходе изучения на 4 курсе клинической фармакологии (252 ч.) и фармакотерапии (108 ч.) на 5 курсе обучения у студентов формируются профессиональные компетенции выпускникапровизора: способность к оказанию консультативной помощи медицинским работникам и потребителям лекарственных препаратов в соответствии с инструкцией по применению лекарственных средств. Для этого следует знать фармакокинетику основных групп лекарственных препаратов, принципы фармакотерапии основных патологических состояний; уметь прогнозировать эффективность и безопасность фармакотерапии; владеть методами оценивания и прогнозирования результатов лекарственного взаимодействия, методами выявления положительных и нежелательных лекарственных реакций; прогнозировать риск развития побочных эффектов лекарственных препаратов.

С учетом перехода на новый учебный план ведется подготовка к преподаванию новой дисциплины «Фармацевтическое информирование».

Эта дисциплина должна сформировать у выпускника фармацевтического факультета знания по ряду вопросов: особенности применения и хранения лекарственных препаратов в домашних условиях, особенности применения лекарственных средств среди пациентов разного возраста. На практических занятиях должны быть сформированы умения грамотного фармацевтического консультирования при отпуске как рецептурных, так и безрецептурных лекарственных средств.

\section{О БСУЖДЕНИЕ}

Существует более широкое понимание консультативной помощи провизора, которая определяется как «фармацевтическая опека» и обозначает комплекс взаимодействия провизора и пациента, провизора и врача в течение всего периода лекарственной терапии. Провизор оказывает консультативную помощь медицинским работникам и потребителям лекарственных средств. Работник первого стола консультирует население по вопросу правильного хранения и утилизации ЛС в домашних условиях; разъясняет способы коррекции побочных реакций ЛС и их профилактики; осуществляет замену отсутствующих в аптеке ЛС их аналогами с учетом лекарственной формы и противопоказаний к назначению. Он должен уметь использовать информацию об ЛС в инструкциях по медицинскому применению, листках-вкладышах, на первичной и вторичной упаковках, а также протоколы фармацевтического консультирования, быть готовым к анализу и публичному представлению медицинской информации на основе доказательной медицины и др. Таким образом, проведение фармацевтической консультации невозможно без развития ключевой компетенции - способности и готовности оказывать консультативную помощь населению по вопросам применения и совместимости лекарственных средств $[1,5]$.

Ряд профессиональных компетенций формируется в ходе изучения фармакотерапии. Приобретенные знания об особенностях этиологии и патогенеза основных форм патологии дают студентам обоснование подходов к этиотропному, патогенетическому и симптоматическому лечению и профилактике заболеваний. Фармацевтическое консультирование при реализации безрецептурных лекарственных средств в рамках «ответственного самолечения» включает подбор лекарственного препарата для симптоматического лечения на основе основных форм патологии, а также выявление симптомов, требующих обязательного обращения к врачу, а в некоторых случаях и оказания первой помощи в торговом зале аптечной организации при неотложных состояниях у посетителей до приезда бригады скорой помощи [7].

Формирование вышеуказанных компетенций целесообразно проводить в условиях деятельности студента, максимально приближенных к профессиональной среде. Производственная практика по клинической фармакологии и фармакотерапии в условиях аптеки представляет собой один из эффективных инструментов развития базовых компетенций студента фармацевтического факультета в условиях выхода студента из «зоны комфорта» (привычная поддерживающая среда в стенах университета) с полным погружением в профессиональноориентированную среду непосредственно на рабочем месте. При этом освоение фармацевтиче- 
ского консультирования является первоочередной задачей. Фармацевтическая консультация при отпуске рецептурного и безрецептурного ЛС, назначенного врачом, включает информирование о способе применения, условиях хранения, возможных нежелательных эффектах, времени наступления эффекта.

К сожалению, из рабочего плана подготовки специалистов-провизоров в ДонНМУ в настоящее время изъята такая дисциплина, как фармацевтическая опека, а также производственная практика по клинической фармакологии.

Именно они позволяют наилучшим образом сформировать у студентов такие компетенции: обеспечение безопасности фармакотерапии, генерической замены; представление о ключевых отличиях препаратов внутри фармакологической группы, основных показаниях к применению и противопоказаниях, профилактике возможных нежелательных эффектов фармакотерапии. Поэтому нам приходится формировать у студентов компетенции, связанные с фармацевтической опекой посетителей аптек, на практических занятиях по клинической фармакологии и фармакотерапии в ходе решения ситуационных задач и обсуждения материала изучаемых тем.

Особое внимание уделяется формированию компетенции самостоятельной и самообразовательной работы студентов, поскольку подготовка квалифицированных работников, готовых к постоянному профессиональному росту, невозможна без умения применять базовые научнотеоретические знания для решения теоретических и практических задач, умения учиться, повышать свою квалификацию и работать самостоятельно. С этой целью на кафедре используются эффективные формы самостоятельной работы: написание рефератов, подготовка докладов с мультимедийной иллюстрацией, оформление тематических стендов. Не менее 60\% рабочего времени практического занятия отводится на самостоятельную контролируемую работу учащихся в виде выполнения обучающих заданий. Доступные для студентов темы рабочей программы предлагаются для самостоятельного изучения с помощью подготовленных кафедрой методических материалов, разработанных учебно-методических пособий. В рабочих программах отводятся часы на самостоятельную внеаудиторную контролируемую рабо- ту студентов: 112 часов по фармакологии, 40 часов по клинической фармакологии и 56 часов по дисциплине «Фармакотерапия. Доклинические и клинические исследования новых лекарственных средств». Результаты этой работы мы проверяем в ходе итогового модульного контроля, а также государственного экзамена.

С целью формирования индивидуализированных обучающих сред в виде сетевого ресурса в 2014 году в Донецком национальном медицинском университете им. Горького создана «Интерактивная обучающая среда» (ИОС), развернутая на базе платформы Moodle. Каждый обучающий курс включает как учебно-методические материалы (календарно-тематические планы, методические пособия, мультимедийные презентации лекций), так и материалы для самостоятельной подготовки студентов (перечень вопросов по теме, алгоритм последовательности ее изучения, рекомендованную литературу, краткое изложение содержания темы, наборы тестов для самоконтроля исходного и итогового контроля знаний ее материала) [8]. Таким образом, роль преподавателя изменяется: акцент в его деятельности смещается с традиционно контролирующей роли на функцию организации и управления самообразовательной деятельностью учащихся.

\section{З А К ЛЮ Ч Е ИЕ}

В информационном обществе, где знания, профессионализм играют решающую роль, результативность системы образования становится ключевым фактором развития общества. Проводимая на кафедре фармакологии и клинической фармакологии работа позволяет обеспечить компетентностный подход в формировании высококвалифицированных конкурентоспособных специалистов-провизоров, обучающихся на очном и заочном отделениях фармацевтического факультета ДонНМУ. С целью повышения результатов формирования компетенций специалистов этого профиля в плане освоения фармацевтического консультирования и приближения к требованиям международных стандартов высшего образования было бы целесообразным возобновить преподавание дисциплины «Фармацевтическая опека» и производственную практику по клинической фармакологии. 


\section{С.В. Налётов, Н.В. Конышева, Я.Ю. Галаева, И.А. Сидоренко, О.С. Налётова,} Т.А. Твердохлеб, М.М. Алесинский, Э.Л. Белевщова

\section{ГОО ВПО «Донецкий национальный медицинский университет имени М. Горького», Донецк \\ ПРИМЕНЕНИЕ КОМПЕТНОСТНОГО ПОДХОДА В ОБУЧЕНИИ СТУДЕНТОВ ФАРМАЦЕВТИЧЕСКОГО ФАКУЛЬТЕТА НА КАФЕДРЕ ФАРМАКОЛОГИИ И КЛИНИЧЕСКОЙ ФАРМАКОЛОГИИ}

В статье показана роль кафедры фармакологии и клинической фармакологии ДонНМУ в формировании компетенций выпускников фармацевтического факультета. Определены функции самообразования студентов как средства формирования профессионально-личностной компетенции будущего специалиста-провизора.

Ключевые слова: кафедра фармакологии и клинической фармакологии, профессиональные компетенции, выпускник-провизор.

S.V. Nalyotov, N.V. Konysheva, Y.Y. Galayeva, I.A. Sidorenko, O.S. Nalyotova,

T.A. Tverdohleb, M.M. Alesinsky, E.L.Belevtsova

SEI HPE «M. Gorky Donetsk National Medical University», Donetsk

\section{APPLICATION THE COMPETENCE APPROACH TO THE TRAINING OF PHARMACEUTICAL FACULTY STUDENTS ON THE DEPARTMENT OF PHARMACOLOGY AND CLINICAL PHARMACOLOGY}

The role of department of pharmacology and clinical pharmacology in the process of formation the competences of pharmaceutical graduates is considered. This article also defines the functions of self-education work of students as a means of forming a professional-personal competence of pharmacists.

Key words: department of pharmacology and clinical pharmacology, professional competences, pharmacists.

\section{ЛИТЕРАТУРА}

1. Акулёнок А.В., Соболенко Т.М., Солкин А.А., Антонова Е.Г., Курлюк О.В. Фармацевтическое консультирование: стратегии реализации компетентностного подхода. Медицинское образование XXI века: компетентностный подход и его реализация в системе непрерывного медицинского и фармацевтического образования: материалы Республиканской научно-практической конференции. Витебск; 2017: 343-348.

2. Государственный образовательный стандарт высшего профессионального образования по специальности 33.05.01 Фармация (квалификация: «провизор»). Донецк, 2017. -18 с. Утвержден приказом Министерства образования и науки Российской Федерации от 11 августа 2016 г. N 1037.

3. Игнатенко Г.А., Джоджуа А.Г., Первак М.Б. Реализация компетентностного подхода в Донецком национальном медицинском университете им. М. Горького в историческом аспекте и на современном этапе. Реализация компетентностного подхода на додипломном и последипломном этапах высшего профессионального образования: материалы научно-методической конференции 18 апреля 2018. Донецк; 2018: 4-17.

4. Митрофанова К.А., Сергеева Н.Н. Компетентность и интеграция в медицинских ВУЗах. Высшее образование сегодня. 2015; 4: 13-16.

5. Олейникова Т.А., Дрёмова Н.Б. Изучение профессионально важных качеств фармацевтических кадров. Медицинское образование XXI века: компетентностный подход и его реализация в системе непрерывного медицинского и фармацевтического образования: материалы Республиканской научно-практической конференции. Витебск; 2017: 427-429.

6. Пешев Л.П., Ляличкина Н.А. Реальные пути повышения качества высшего медицинского образования в России. Современные проблемы науки и образования. 2017; 5: 29-32.

7. Федеральный государственный образовательный стандарт высшего образования по специальности 33.05.01.

\section{REFERENCES}

1. Akulenok A.V., Sobolenko T.M., Solkin A.A., Antonova E.G., Kurlyuk O.V. Farmatsevticheskoe konsul'tirovanie: strategii realizatsii kompetentnostnogo podkhoda. Meditsinskoe obrazovanie XXI veka: kompetentnostnyi podkhod i ego realizatsiya $\mathrm{v}$ sisteme nepreryvnogo meditsinskogo i farmatsevticheskogo obrazovaniya: materialy Respublikanskoi nauchno-prakticheskoi konferentsii. Vitebsk; 2017: 343-348 (in Russian).

2. Gosudarstvennyi obrazovatel'nyi standart vysshego professional'nogo obrazovaniya po spetsial'nosti 33.05.01 Farmatsiya (kvalifikatsiya: «provizor»). Donetsk, 2017. -18 s. Utverzhden prikazom Ministerstva obrazovaniya i nauki Rossiiskoi Federatsii ot 11 avgusta 2016 g. N 1037 (in Russian).

3. Ignatenko G.A., Dzhodzhua A.G., Pervak M.B. Realizatsiya kompetentnostnogo podkhoda v Donetskom natsional'nom meditsinskom universitete im. M. Gor'kogo $\mathrm{v}$ istoricheskom aspekte i na sovremennom etape. Realizatsiya kompetentnostnogo podkhoda na dodiplomnom i poslediplomnom etapakh vysshego professional'nogo obrazovaniya: materialy nauchno-metodicheskoi konferentsii 18 aprelya 2018. Donetsk; 2018: 4-17 (in Russian).

4. Mitrofanova K.A., Sergeeva N.N. Kompetentnost' i integratsiya v meditsinskikh VUZakh. Vysshee obrazovanie segodnya. 2015; 4: 13-16 (in Russian).

5. Oleinikova T.A., Dremova N.B. Izuchenie professional'no vazhnykh kachestv farmatsevticheskikh kadrov. Meditsinskoe obrazovanie XXI veka: kompetentnostnyi podkhod i ego realizatsiya v sisteme nepreryvnogo meditsinskogo i farmatsevticheskogo obrazovaniya: materialy Respublikanskoi nauchno-prakticheskoi konferentsii. Vitebsk; 2017: 427-429 (in Russian).

6. Peshev L.P., Lyalichkina N.A. Real'nye puti povysheniya kachestva vysshego meditsinskogo obrazovaniya v Rossii. Sovremennye problemy nauki i obrazovaniya. 2017; 5: 2932 (in Russian).

7. Federal'nyi gosudarstvennyi obrazovatel'nyi standart vysshego obrazovaniya po spetsial'nosti 33.05.01. «Farmatsi- 
«Фармация» (уровень специалитета), 2019. (https:// classinform.ru/fgos.html)

8. Хомутов Е.В., Шатова О.П., Зинкович И.И., Зенин О.К. Опыт организации интерактивной обучающей среды на базе платформы MOODLE в условиях военного времени. Медицинское образование XXI века: компетентностный подход и его реализация в системе непрерывного медицинского и фармацевтического образования: материалы Республиканской научнопрактической конференции. Витебск; 2017: 156-157.

9. Щастный А.Т., Коневалова Н.Ю., Городецкая И.В., Кабанова С.А., Кугач В.В. Исследование формирования профессиональной компетентности студентов. Медицинское образование XXI века: компетентностный подход и его реализация в системе непрерывного медицинского и фармацевтического образования: материалы Республиканской научно-практической конференции. Витебск; 2017: 3-5. ya» (uroven' spetsialiteta), 2019 (in Russian). (https:// classinform.ru/fgos.html)

8. Khomutov E.V., Shatova O.P., Zinkovich I.I., Zenin O.K. Opyt organizatsii interaktivnoi obuchayushchei sredy na baze platformy MOODLE v usloviyakh voennogo vremeni. Meditsinskoe obrazovanie XXI veka: kompetentnostnyi podkhod i ego realizatsiya $v$ sisteme nepreryvnogo meditsinskogo i farmatsevticheskogo obrazovaniya: materialy Respublikanskoi nauchno-prakticheskoi konferentsii. Vitebsk; 2017: 156-157 (in Russian).

9. Shchastnyi A.T., Konevalova N.Yu., Gorodetskaya I.V., Kabanova S.A., Kugach V.V. Issledovanie formirovaniya profescional'noi kompetentnosti studentov. Meditsinskoe obrazovanie XXI veka: kompetentnostnyi podkhod i ego realizatsiya $\mathrm{v}$ sisteme nepreryvnogo meditsinskogo i farmatsevticheskogo obrazovaniya: materialy Respublikanskoi nauchno-prakticheskoi konferentsii. Vitebsk; 2017: 3-5 (in Russian). 